\title{
SCIENTIFIC AND PRACTICAL ASPECTS \\ OF THE FORMATION OF ECOLOGICALLY SAFE SYSTEMS \\ OF IRRIGATED AGRICULTURE IN THE CONDITIONS OF THE SOUTH OF UKRAINE
}

Vozhegova R. A.

\section{INTRODUCTION}

On the basis of the modeling of climate changes processes, conducted by the international team of the scientists of the Cambridge group under the aegis of the FAO UNO, further rise in the air temperature in the range from 2 to $6^{\circ} \mathrm{C}$ in the period until 2100 is predicted ${ }^{1}$. This increase in the temperature and $\mathrm{CO}_{2}$ concentration in the air will have a direct impact on the biosphere of the Earth, including the productivity of the agro-industrial complex, the yield and quality of products of crops. Negative climate changes in the nearest future include the rise in the air temperature, strengthening of the drought effects, reduction of snow cover, disturbance of the uniformity of precipitation distribution, which in complex will lead to the intensification of erosion processes and soils degradation.

Increasing drought of the climate has caused the need to change approaches to the formation of agricultural systems, especially in Southern Steppe of Ukraine. For the last 45 years, the amount of effective and positive temperatures during the vegetation period in this region has increased almost to $700^{\circ} \mathrm{C}$ that has prolonged its duration by 12-14 days ${ }^{2}$. At the same time, it should be noted that the productivity of the plant sector, as well as of the agriculture on the whole, strongly depends on the impact of climatic factors ${ }^{3}$.

Irrigation in the conditions of a severe deficit of natural moisture is one of the main factors of countering the negative effects of global warming and improving the productivity of the crop industry. Optimum interaction with other constituents of agriculture and complex mechanization favors to the intensive

\footnotetext{
${ }^{1}$ Наукові основи охорони та раціонального використання зрошуваних земель / за наук. ред. С. А. Балюка, М. І. Ромащенка, В. А. Сташука. Київ: Аграрна наук, 2009. 624 с.

2 Сніговий В. С. Проблеми землеробства й ефективність сучасного виробництва. Таврійський науковий вісник. 2003. Вип. 27. С. 29-33.

${ }_{3}^{3}$ Бабич А. О. Світові земельні, продовольчі і кормові ресурси. Київ: Аграрна наука, 1996. $133 \mathrm{c}$.
} 
use of heat, light, nutrients, moisture by plants that in the complex provides an effective use of land resources, promotes obtaining of high and sustainable yields of different by biological features and genetic potential crops ${ }^{4}$.

The use of irrigation causes fundamental changes in the natural ecosystems of the Steppe region - changes in soil moisture, decrease of the temperature and increase of the humidity of surface air, etc. Besides, there are a number of less noticeable, but no less important consequences - the change of mineral composition of soil, physical, physical-chemical and biological properties of different soil horizons. Experiments, conducted in recent times, show that because of the lack of sufficient environmental literacy of agricultural producers, proper control by the state bodies for the conditions of the environment, the lack of environmentally friendly equipment and agricultural technologies, the desire of getting the maximum number of agricultural products, even at the expense of the increase in the degree of intensity of the load on agricenoses, a threat of further critical deterioration of the ecological conditions of the irrigated ecosystems occurred ${ }^{5}$.

To prevent the undesirable consequences of agricultural activity, it is necessary to develop and apply a number of agro-technological measures: maintenance of crop rotations, cultivation of perennial forage herbs, differentiated methods of soil tillage, use of the varieties and hybrids with a resistance to the insects and diseases, use of biological methods for combating harmful organisms, etc. In the historical aspect, the attempts of farmers to overcome the negative impact on the environment through the application of fertilizers, lime, gypsum, irrigation or drainage, and other agricultural measures has been started at the BC times. However, their explanation, reasonable and rational use remain problematic even at the present time. Particularly noticeable impact on the environment is observed in the conditions of irrigation, when due to the receipt of a large amount of water at the application of artificial humidification, there is a significant transformation of almost all abiotic and biological components of agrocenosis that requires the use of absolutely different methodological approaches to the crop science.

In the countries of the European Union in recent years, certain attention is paid to the study of the impact of agromeliorative measures, including the simultaneous use of irrigation and fertilizers, considering the changes in environmental conditions, because in the modern conditions intensification of agricultural production needs the increase in the efficiency of agriculture,

\footnotetext{
${ }^{4}$ Силва Ж. Г., Нвазе К. Ф., Казин Э. Достижение нулевого голода. Критическая роль инвестиций в социальную защиту и сельское хозяйство. ФАО ООН. Рим, 2016. С. 12-14.

${ }^{5}$ Gathala M. K., Timsina J., Islam Md. S. Et cetera Conservation agriculture based tillage and crop establishment options can maintain farmers' yields and increase profits in South Asia's rice-maize systems. Evidence from Bangladesh. Field Crops Research. 2014 P. 85-98.
} 
rational use of water resources, optimization of the fertilizers use with a decrease in their negative impact on the environment and scientifically substantiated accounting of the needs in agricultural resources. These developments require a comprehensive approach with the development of the predictive models to assess the effect of water use on hydrological and hydrochemical conditions, the model of forecasting the balance of nitrogen, phosphorus, etc. Intensification of agricultural production on the meliorated lands leads to a decrease in the natural soil fertility due to the uptake by crops of nutrient and biologically active elements. Another problem is connected with soil salinity increase under the use of irrigation that could result in salinization and alkalination ${ }^{2}$.

The management of nutrition and salt regimes is an important task of agriculture and implies the use of technologies based on the modern achievements of science and technology for these purposes. Fertilizers and ameliorants in irrigated agriculture should be applied simultaneously with irrigation water, using the flow energy and the ability of water to dissolve them. In this case, their application could be subdivided and performed in the required quantities and in the necessary periods of vegetation that would provide the optimization of plants productive processes, prevent surface runoff and untimely decomposition of fertilizers and ameliorants substances.

During the twentieth century, irrigation has become widespread in the world, currently more than 345 million hectares are irrigated on the planet, which is $21 \%$ of the total arable land, on which it is produced more than $40 \%$ of all agricultural products, that is because the productivity of one irrigated hectare more than twice exceeds the yield of plant products of non-irrigated area. High efficiency of artificial humidification led to the solving the food security of mankind, as the rapid growth of irrigated lands has led to a significant reduction in the global food prices index from $2.2 \%$ in 1971-1980 years to $0.8 \%$ - in 20002005.

At the moment, due to the global climate change, which manifests itself in the increase of air temperatures, reduction of its relative humidity, reduction of the amount and disturbance of the uniformity of precipitation distribution, increase in the deficit of qualitative irrigation water makes for the necessity to use new methodological approaches to the organization of artificial humidification at both regional and micro-local levels ${ }^{6}$.

In many countries in the world, small farms do not have enough money, time, energy or water, because existing irrigation technologies are extremely resource consumptive. Soil tillage, fertilization, sowing, plant care, harvesting

\footnotetext{
${ }^{6}$ Asfaw S., Maggio G. Gender integration into climate-smart agriculture. Tools for data collection and analysis for policy and research. Food and Agriculture Organization of the United Nations. Rome 2016. 20 pp.
} 
requires large labor costs and time, diesel pumps need fuel, electric - connection to the networks and electricity, but sometimes water does not come to the root zone of plants, and, for example, evaporates into the air (at watering by sprinkler irrigation), runs off the fields (at surface way of watering), moves into deep layers of soil and becomes inaccessible (watering by flooding) ${ }^{7}$.

Intensive cultivation technologies make for the need to use large amounts of resources to obtain optimum levels of yields. Therefore, important scientific and practical significance has the application of innovative approaches to the formation of systems of agriculture on irrigated lands, which are based on the principles of water-and resource-saving, development of the norms for consumption of irrigation water, fertilizers, pesticides and biopreparations, considering the location of the root system of crops, the use of alternative energy sources, etc ${ }^{8}$.

Worldwide, agricultural water consumption is about $70 \%$ and energy consumption is about $30 \%$. Therefore, the questions of the reduction of costs of both irrigation water and energy during watering are strategic ones. Realizing that many agricultural producers are limited by resource supply, the scientists of agrarian science should offer a set of measures to save and minimize water consumption, energy, labor and resources through the development and testing of the latest technologies, existing on the considering the costs of these four resources, which may have an important value and increase the economic efficiency of irrigated agriculture ${ }^{9}$.

The world energy crisis, which has started in the second half of the twentieth century, resulted in the necessity of development and implementation of resource-saving, low-waste and zero-waste technologies in all sectors of the national economy, including crop production. Moreover, the questions of resource- and energy saving in the conditions of irrigation are particularly critical. Existing cultivation technologies no longer met the requirements of time, so the production required innovative resource-saving concepts, which would form the highest level of plant productivity, and also simultaneously in full volume would contribute to the saving water and other resources, would provide complete use of irrigation water and fertilizers by crops, etc. ${ }^{5}$.

Many studies have proved that the neglection of the elements of crop cultivation technologies and violation of the ecological balance in

\footnotetext{
${ }^{7}$ McCarthy N. Understanding agricultural households ' adaptation to climate change and implications for mitigation: land Management and investment options. Integrated Surveys on Agriculture. Washington D.C., USA: LEAD Analytics Inc. 2011 P. 42 - 47.

${ }^{8}$ Снеговой В. С., Гаврилица А. О. Орошение: от древнего искусства до современной науки. Кишинев: Штипнца, 1989. 135 с.

${ }^{9}$ Нетіс І. Т. Зміна клімату в зоні зрошення. Зроиуване землеробство. 1994. Вип. 39. C. $7-12$.
} 
agrolandscapes due to the neglection of all causative relations that ensure the functioning of ecosystems, causes the disruption of closed bicycles, destruction of the natural ability of main components to self-healing and in general to the reduction of the efficiency of irrigated agriculture. At the same time, at the expense of the positive influence of irrigation on the productive processes of plants in agrophytocenosis at high technological level of agriculture it is possible to increase yields 2-3 times, and in dry years - 4-5 times. Therefore, in our opinion, in order to obtain high and sustainable yields on irrigated lands, it is necessary to optimize the productive processes, to reduce expenditures of irrigation water per unit of plant products, to develop and apply modern cultivation technologies that comprehensively consider biological features of crops, the nature of their water consumption, have increased adaptability to weather conditions, and are characterized by high economic, energy and ecological parameters .

\section{The directions of the reduction of resource expenditures at artificial humidification in the South Steppe of Ukraine}

Mainly two methods of vegetation irrigation are used in the South of Ukraine - sprinkler over-head irrigation and irrigation by furrows. Sprinkler irrigation - by the means of machines DDA-100 MA, Fregat, DDN-45, Kuban, Valmont et al. In the future, combined methods of vegetation watering (for example, drip and aerosol - at the combination of the most economical benefits and ecological safety) will be used. Furrow irrigation is a simple and mostly cheap way, but it is more laborious and requires a particularly well-planned surface of the field. It can be used only if groundwater lays deep (not less than $2.0 \mathrm{~m}$ ). The watering furrows are made at the last row tillage, temporary canals and the output furrows - by the means of the canal-diggers KZU-0.3, KOR-500, etc. The better the field surface is planned (aligned), the greater the length of the watering furrows may be and the higher labor productivity of watering will be. If the field has the optimal slope (0.004-0.012) and is well-planned, the length of the irrigation furrows can be up to $200 \mathrm{~m}$ or more, and in the fields with a lower slope the furrows with the length of 50-100 m should be used.

The works of domestic and foreign scientists have found that in the conditions of irrigation, each crop, as well as some varieties and hybrids, have a biological reaction on a separate technological element, in particular, irrigation, mineral nutrition background, plants density, soil tillage system, etc. Therefore, there is a need to use high-productive varieties and hybrids of the intensive type, which are able to provide maximum manifestation and disclosure of potential genetically determined characteristics of plant productivity in the conditions of irrigation, in particular, at drip and micro-sprinkler irrigation, increased mineral 
nutrition, application of the systems of integrated plant protection and differentiated soil tillage.

Drip irrigation in 2-3 times decreases the cost of irrigation water per unit of sowing area, increases yields and improves the quality of plant products. However, the main advantage of this method of artificial humidification is saving resources and increasing their payback by the unit of additional yield. Drip irrigation due to its numerous advantages has been used for the first time over 100 years, but until nowadays it requires improvement and increase of its resource-saving direction. The system of precise agriculture, which includes the use of micro-irrigation (including drip irrigation), is an innovative technology that differs significantly from other irrigation technologies of crops. Its use provides the possibility to obtain the maximum yield of onion at the minimum expenditures. It is advisable at irrigation, along with the use of fertilizers, to use biopreparations for the optimization of the growth and development of plants, increase of their resistance to environmental conditions. Therefore, resourcesaving technologies of artificial humidification should be adapted to the unique features of each enterprise and region ${ }^{10}$.

Drip irrigation allows obtaining friendly sprouts and distribute the mineral fertilizers evenly in the root-zone layer. Distribution of watering norms by the days of cultivation of onions at drip irrigation is as follows: 1-30 day - 20$25 \mathrm{~m}^{3} / \mathrm{ha}$; $31-50$ day $-25-30 \mathrm{~m}^{3} / \mathrm{ha} ; 51-100$ day $-35-45 \mathrm{~m}^{3} / \mathrm{ha}$.

Unlike sprinkling, drip irrigation is based on the flow of water into the root zone of plants. The number and frequency of water supply is regulated according to the needs of plants. The water comes to every plant evenly. Unirrigated strips of the rows allow performing tillage, harvesting. At drip irrigation, the root system develops better than at any other type of irrigation, with a circle of the roots humidification is thicker. Drip irrigation is the most effective system for plants nutrition. The intensive absorption of nutrients is due to the greater development of the root system, complete humidification and at the expense of good soil aeration and the formation of new roots.

The use of drip irrigation systems simultaneously with the application of fertilizers in solution (so-called «fertigation»), allows you to constantly maintain the soil moisture in the optimum ratio in the system «water - air» in the soil that favors to a higher coefficient of fertilizers absorption by plants. At drip irrigation systems, precise dosing of all elements that are in the solution, including the control of nutrition soil regime, the simulation of fertilizer consumption and to setting their quantity for the planned yield level could be performed. Besides,

\footnotetext{
${ }^{10}$ Сніговий В. С., Жуйков Г. Є., Димов О. М. Економічні важелі еколого-безпечного ведення землеробства на зрошуваних землях Південного Степу. Агроекологічний журнал. Київ, 2003. С. 32-37.
} 
such a system allows to apply a balanced amount of nitrogen, phosphorus, potassium and other nutrients considering the growth stages. and the seasonal requirements of plants. Fertilization through drip systems increases the coefficient of their use by an average of $25-30 \%$, reduces the total use of fertilizers by $15-35 \%$. Fertigation, unlike a conventional drip irrigation, not only provides an efficient use of fertilizers, but helps to prevent contamination of groundwater, does not create conditions for secondary soil salinization and has valuable ecological and economic advantages.

Prospective ways for solving the problems of irrigated agriculture concerning resource conservation and increase of economic efficiency are the use of microirrigation and pumps working on solar power, which has significant agricultural, economic and environmental benefits (Fig. 1).

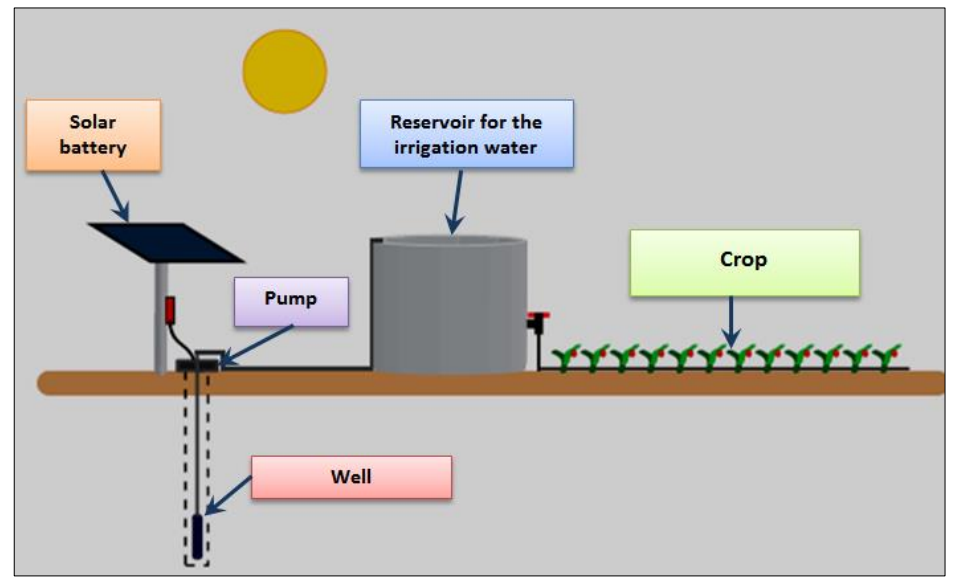

Fig. 1. The scheme of resource-saving irrigation system using solar energy ${ }^{11}$

To optimize irrigation and to reduce the expenditures of irrigation water and energy resources, it is necessary to develop and apply innovative systems of artificial humidification with the maximum simplification and low cost. Thus, the important value has the consideration of local irrigation conditions and irrigation area for the manufacturing of pumps.

In recent years, wide distribution was obtained by the pumps with a power of 40-200 Watts, which are used for the irrigation of small fields with

${ }^{11}$ Fischer R. A., Byerlee D., Edmeades G. O. Crop yields and Global Food Security: Will yield increase continue to feed the world? Australian Centre for International Agricultural Research. 2014. No. 158. P. 52 - 59. 
an area of 1000 to $5000 \mathrm{~m}^{2}$. In such conditions, it is possible to use solar batteries for power supply of such pumps and to compensate the expenditures for irrigation during one or two seasons of crops cultivation ${ }^{12}$.

\section{Scientific substantiation of crops cultivation technologies on the irrigated lands of the South of Ukraine}

Crops cultivation is connected with the action and interaction of many factors, that is testified by the influence of natural and anthropogenic conditions. At the level of each farm to improve the environmental friendliness of agrotechnical and melioration measures and agricultural methods, it is necessary to assess their impact on the soils and agroecosystems. In the South of Ukraine, the most effective measure of soil water regime improvement is artificial humidification, which allows to significantly increase the productivity of agriculture. Perennial field researches of the Institute of Irrigated Agriculture of the National Academy of Agrarian Sciences of Ukraine and other scientific institutions have proved that due to the artificial humidification it is possible to create favourable conditions for realization of potential possibilities of varieties and hybrids, and provide a substantial increase in gross production volumes per the unit of sowing area.

Increasing the efficiency of scientific research and competitiveness of scientific developments in the field of irrigated agriculture in southern region of Ukraine is a significant lever of stabilization of agricultural production in the arid climate and one of the priority directions of the state policy. The Institute of Irrigated Agriculture of NAAS has been developing and constantly improving the systems of irrigated agriculture in the areas of the Steppe zone, which allow to receive the 3-5 times higher yields in comparison to non-irrigated conditions, and irrigation regimes are oriented to the biological and genetic features of modern varieties and hybrids saving $15-40 \%$ of irrigation water actually without the loss of yields.

Theoretical developments on the optimization of soil processes on the irrigated lands substantiate the scientific bases of rational and environmentally-safe application of fertilizers and ameliorants. Wide distribution obtained the use of new resource-saving systems of crops fertilization, which every year are introduced in the areas of Kherson, Mykolaiv, Dnipropetrovsk regions on the area of 50 thousand ha and provided the reduction of expenditures for mineral fertilizers by $24-72 \%$, compared to the accepted norms. The developments of the Institute were included as a constituent part in the «Prospective plan for preservation and increase of fertility of soils in Kherson region».

12 Resource-Smart technology. Bridging the design gap between the developed and developing worlds. Url: https://www.ideglobal.org/story/resource-smart-technology (date of access 12.01.2019). 
Introduction of the developed by the Institute of Irrigated Agriculture of NAAS «Methods for determination of the payback of irrigation water and reimbursement for its supply» will increase the efficiency of the water supply complex and irrigated agriculture in southern region on the whole, providing the possibility of more rational allocation of funds.

The development of the Institute consists of scientific and technical base of agriculture conduction on the irrigated lands in southern region. In short crop rotations a system of soil-protective energy-saving soil tillage, which provides saving of fuel-lubricants materials (by 20\%) under a decrease in the energy intensity of the process (by 40\%), became widespread in the region.

The improved at the Institute crop cultivation technologies is being implemented on the irrigated lands in Kherson, Mykolaiv, Odesa and Dnipropetrovsk regions on the area (thousand hectares): winter wheat -150 , soybean - 35, vegetable crops - 25. Water-saving regimes of crops irrigation, which ensure saving of irrigation water and energy resources and obtaining 4.5-5.5 million UAH of pure profit, are used in the farms of Kherson, Mykolaiv, Dnipropetrovsk, Zaporizhzhya regions on the area of 300 thousand ha.

In the field experiments of the Institute of Irrigated Agriculture it was established that due to the best indexes of the bulk density, porosity and water permeability, the content of moisture at the time of the spring regrowth of winter crops and at the appearance of spring crops sprouts at different-depth systems of plowing and plowless tillage were 3.5-7\% higher than at the shallow single-depth system. Water consumption for the formation of one ton of products in all crop rotations was the lowest at the different-depth plowing and ranged from $723 \mathrm{~m}^{3} / \mathrm{t}$ in crop rotation with $75 \%$ share of cereals up to $973 \mathrm{~m}^{3} / \mathrm{t}$ under the reduction of the cereals share to $50 \%$ and up to $1100 \mathrm{~m}^{3} / \mathrm{t}$ - under the reduction to $25 \%$. This pattern is also observed at the systems of the different-depth and single-depth shallow plowless tillage with the decrease, respectively, by $5-10 \%$ and $50-60 \%$.

More favorable conditions for the accumulation of nutrients in the soil layer of $0-40 \mathrm{~cm}$ were created at the beginning of the spring vegetation of crops in the crop rotation with $75 \%$ share of cereals and on the background of the different-depth plowing basic tillage.

Replacement of plowing with the plowless deep basic tillage led to the decrease of the content of nitrates, mobile phosphorus and exchangeable potassium, respectively, by 10,17 and $8 \%$, and at the use of shallow plowless loosening these indexes were lower, respectively, by 27, 23 and $13 \%$. This pattern was observed in the crop rotation No. 1 with 25 and No. 2 with $50 \%$ share of cereals, at the same time, the indexes of the nutrients content were significantly lower.

The highest yield of crops and crop rotation productivity was provided by the crop rotation No. 3 with $75 \%$ share of cereals and $25 \%$ share of industrial crops at the different-depth plowing tillage, where its indexes 
averaged to $10.3 \mathrm{t} / \mathrm{ha}$, with a profit of 37.9 thousand $\mathrm{UAH}$ and profitability level of $187 \%$ (Fig. 2).

At the same time, a single-depth shallow one provided the level of profitability, which decreased to $103 \%$. In the first and second crop rotations, the profit and profitability level were significantly lower, at the same time, the regularity in regard to the methods and depths of the basic tillage saved.

In the field researches in the direction of the optimization of cultivation technology of new corn hybrids of different FAO groups at different ways of irrigation and quality of irrigation water, the level of mineralization, ion-salt composition of irrigation water and its irrigational assessment according to the DSTU-2730-2015 were made. Basic information on the economic efficiency of the complex action of new hybrids of corn, different ways of irrigation in the conditions of the Ingulets and Kakhovka irrigation systems was obtained.

It was found that under the watering with water of the Class II from the Ingulets irrigation system, the yield of corn hybrids decreased by $5-10 \%$, compared to the results of the studies obtained in the Kakhovka irrigated array (Table 1).

The highest grain yield of 14.1-18.8 t/ha was formed by the hybrids with FAO 380-430 Azov and Ararat, and at drip irrigation the absolute advantage was of the hybrid Aral, the grain yield of which increased to 18.7-19.0 t/ha.

One of the main factors of the intensification of production in irrigated agriculture is plant breeding developments. The Institute of Irrigated Agriculture creates the newest varieties and hybrids with genetically predetermined adaptability to the conditions of irrigation. Over 70 varieties and hybrids of winter wheat, soybean, corn, alfalfa, tomato and other crops have been created.

Winter wheat varieties have a potential yield of 8-11 t/ha of grain, and high adaptive ability. New alfalfa varieties combine high potentials of forage, seed and nitrogen-fixing productivity with wide adaptive abilities to the biotic and abiotic conditions of the environment, which can accumulate in the soil up to $0.27 \mathrm{t} / \mathrm{ha}$ of biological nitrogen. High-productive soybean varieties of different ripeness groups are created, with a yield level of 3.7-5.6 $\mathrm{t} / \mathrm{ha}$ of seeds, high protein content of $39-42 \%$ and fat content of $20-23 \%$. Besides, new varieties and hybrids have the advantage of resistance to diseases and lodging.

The work on the breeding of the main crops - winter wheat, corn, soybean, tomato, alfalfa, etc. is carried out at the high level at the Institute. The GMO-free varieties and hybrids are created, which is a significant competitive advantage for Ukraine, the EU countries and for other countries in the world, and it allows to obtain plant products, which are qualified as 
ecologically safe, has an increased demand on the domestic and foreign markets.

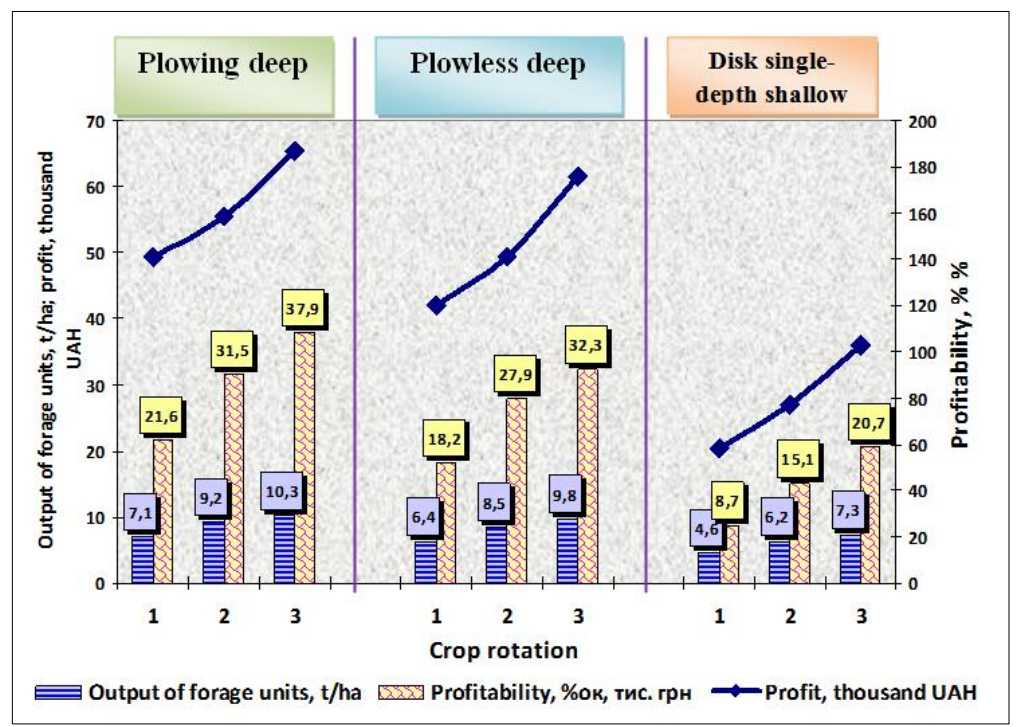

Fig. 2. Productivity and cost-effectiveness indexes of the crop rotation functioning under different soil tillage systems

The development of seed-breeding systems at the Institute is the result of a long-term work in the field of biotechnology with the development of the principles of a potato seed system creation for the irrigated conditions of the South of Ukraine through the obtaining original material by the combination of new scientific approaches.

New directions of agricultural development are the introduction of organic farming systems, the cultivation technologies of unconventional (socalled «niche») and drought-resistant crops, adapted to the regional climatic conditions. The new crop, which is examined by the scientists of the Institute, is a perennial vegetable plant - asparagus. This vegetable, especially its young shoots, has a great value by the gourmets throughout the world, and is one of the most delicious vegetable crops. The Institute created a unique and only in Ukraine variety of sweet white clover, which has a high forage and seed productivity, increased drought resistance, high capacities of phytoremediation, resistance to pests and pathogens infestation. There also 
are the field experiments on the cultivation of saffron seed, which has great prospects for the introduction on the irrigated lands of the South of Ukraine.

Table 1

The grain yield of corn hybrids at different ways of irrigation and irrigation regimes, $t /$ ha (average for 2016-2018)

\begin{tabular}{|c|c|c|c|c|c|c|}
\hline № & Hybrid & FAO & $\begin{array}{c}\text { Irrigation } \\
\text { with DDA } \\
\mathbf{1 0 0 M A ,} \\
\text { Ingulets } \\
\text { irrigation } \\
\text { array, TAW } \\
\text { at 80\% FC }\end{array}$ & $\begin{array}{c}\text { Drip } \\
\text { irrigation, } \\
\text { Ingulets } \\
\text { irrigation } \\
\text { array, TAW } \\
\text { at 85\% FC }\end{array}$ & $\begin{array}{c}\text { Drip } \\
\text { irrigation, } \\
\text { Kakhovka } \\
\text { irrigation } \\
\text { array, TAW } \\
\text { at 85\% FC }\end{array}$ & $\begin{array}{c}\text { Irrigation } \\
\text { with } \\
\text { Zimmatic, } \\
\text { Kakhovka } \\
\text { irrigation } \\
\text { array, TAW } \\
\text { at 80\% FC }\end{array}$ \\
\hline 1 & DN Pivikha & 190 & 9.75 & 10.10 & 10.76 & 10.57 \\
\hline 2 & Oberih & 190 & 10.61 & 11.00 & 12.10 & 11.54 \\
\hline 3 & Hawtyn & 250 & 12.61 & 12.29 & 13.41 & 13.97 \\
\hline 4 & Galateya & 250 & 12.21 & 11.91 & 13.46 & 12.71 \\
\hline 5 & Korund & 280 & 12.38 & 12.64 & 12.54 & 12.42 \\
\hline 6 & Rostok & 300 & 12.93 & 14.81 & 15.65 & 12.85 \\
\hline 7 & Zbruch & 350 & 12.77 & 14.87 & 15.20 & 12.81 \\
\hline 8 & Vizyr & 350 & 10.61 & 11.43 & 11.72 & 11.48 \\
\hline 9 & Kakhovskyi & 350 & 11.23 & 13.72 & 13.28 & 11.37 \\
\hline 10 & Azov & 380 & 14.09 & 14.25 & 15.34 & 14.57 \\
\hline 11 & Rava & 420 & 14.65 & 15.81 & 16.27 & 14.38 \\
\hline 12 & Arabat & 430 & 14.30 & 18.71 & 18.95 & 14.83 \\
\hline & LSD & & 0.37 & 0.56 & 0.42 & 0.44 \\
\hline
\end{tabular}

The efficiency of agricultural technologies on the irrigated lands is confirmed by their large-scale introduction. In the South of Ukraine, the developed soil tillage system is applied on the area of 200-215 thousand ha. Resource-saving system of fertilization of crops using optimal parameters of the content of nutrients in the soil is implemented on the area of 57.5 thousand ha. At the same time, resource saving on average amounted to $150 \mathrm{UAH} / \mathrm{ha}$. In Kherson region, the cultivation technology of tomato with application in the technological process of own varieties is introduced. It has provided the maximum fruit yield of $115 \mathrm{t} / \mathrm{ha}$, with the dry matter content in fruit up to $7 \%$. The volume of introduction - 1600-2500 ha with the prospects of further its expansion to 10 thousand hectares.

In Ukraine as in other countries of the world there is a critical issue of adaptation of agriculture to the climate change, which manifests itself in drought, increase in temperature and disturbance of uniformity of precipitation distribution. On the basis of the above-mentioned facts, it should be noted that in the context of regional climate change in the South of Ukraine, it is necessary to perform a continuous monitoring of the main agrometeorological indexes, analyze and forecast their changes according to 
the data of the meteorological stations of the region, determine the directions of climate change and make forecasts of changes for 5, 10, 20-year periods.

Considering previous indicators of the climate change, the agrarian scientists should expand directions, program of scientific researches on adaptation of agricultural system to new agroecological situation, which envisages the following:

- Conducting of deep researches on the issues of zoning of territories for crops cultivation on the basis of estimation of natural agroclimatic resources;

- To create new varieties and hybrids of crops with the optimum adaptability to arid conditions and regional climate changes;

- Reduction of share of plow-land and increase of the areas using agromeliorative measures;

- To continue research on the soil formation processes, development of soil fertility preservation measures and prevention of soil degradation;

- Reconstruction and building of new irrigation systems and development of irrigated agriculture, as a guarantor of sustainable yields, effective development of the agrarian sector and rural areas in the zone of irrigation.

\section{CONCLUSIONS}

1. In the conditions of climate change in the irrigated agriculture of Ukraine it is necessary to use intensive technologies of crops cultivation, which are based on the use of innovative principles with the optimization of different methods of irrigation and irrigation regimes, fertilization systems, tillage and plant protection. The structure of acreage and crop rotations on the irrigated lands of Ukraine for rational use of the irrigated lands and prevention of the negative influence of external factors of natural and anthropogenic nature are proposed.

2. The methodological and methodical approaches to the integrated estimation of the irrigated lands for their rational use, prevention of development of the degradation processes, protection and recovery of soil fertility are developed. The resource-saving cultivation technologies of different by the biological characteristics in accordance with the project normative expenses, which are specified by the scientists of the Institute of Irrigated Agriculture and other scientific institutions of NAAS, are improved, scientific approaches to the state-private partnership in the system and management of water resources are proposed, the instruments of the state support and regulation of entrepreneurial activity in the field of irrigated agriculture are determined.

3. For the scientific substantiation for the nearest prospects, the issues of the reduction of all types of resource losses at irrigation and other elements of agrotechnologies in the conditions of global climate change will be of a particular importance. It is required to work out new scientific approaches regarding the application of innovative technologies of drip irrigation on the 
basis of minimization of water, energy, labor and money expenditures, regulation of irrigation water, fertilizers, pesticides and biopreparations, considering the location of the root system of crops to determine the optimal irrigation norms, use of solar energy as an alternative energy source, etc.

4. In the conditions of regional climate change, a great scientific and practical significance will have the research on the zoning of the territories for crops cultivation on the basis of the assessment of natural agroclimatic resources, creation of crops varieties with the optimum adaptability to arid conditions and regional climate changes, reduction of the share plow-land and increase in the areas using agro-meliorative measures, optimization of nutrition regime of soil. Besides, the development and introduction of a system of measures, also at the level of the state, which are directed to the reconstruction of the existing and building of new irrigation systems, development of irrigated agriculture with the aim of the development of the agrarian sector and rural areas in the zone of irrigation.

\section{SUMMARY}

In the conditions of climate change in the irrigated agriculture of Ukraine, it is required to use intensive crops cultivation technologies, which are based on the use of innovative approaches with the optimization of different methods of irrigation and irrigation regimes, fertilization systems, soil tillage and plant protection. The structure of acreage and crop rotations on the irrigated lands of Ukraine for the rational use of irrigated lands and prevention of the negative influence of external factors of natural and anthropogenic nature are suggested. The methodological and methodical approaches to the integrated assessment of the irrigated lands for their rational use, prevention of the development of degradation processes, protection and recovery of soil fertility are developed. The improved resource-saving cultivation technologies of different by the biological properties crops in accordance with the project normative expenses defined by the scientists of the Institute of Irrigated Agriculture and other scientific institutions of NAAS, are proposed, the scientific approaches to the stateprivate partnership in the system and management of water resources are determined, the instruments of the state support and regulation of entrepreneurial activity in the field of irrigated agriculture are suggested.

\section{REFERENCES}

1. Наукові основи охорони та раціонального використання зрошуваних земель / за наук. ред. С. А. Балюка, М. І. Ромащенка, В. А. Сташука. Київ: Аграрна наук, 2009. 624 с.

2. Сніговий В. С. Проблеми землеробства й ефективність сучасного виробництва. Таврійський науковий вісник. 2003. Вип. 27. С. 29-33.

3. Бабич А. О. Світові земельні, продовольчі і кормові ресурси. Київ: Аграрна наука, 1996. 133 с. 
4. Силва Ж. Г., Нвазе К. Ф., Казин Э. Достижение нулевого голода. Критическая роль инвестиций в социальную защиту и сельское хозяйство. ФАО ООН. Рим, 2016. С. 12-14.

5. Gathala M. K., Timsina J., Islam Md. S. et cetera Conservation agriculture based tillage and crop establishment options can maintain farmers' yields and increase profits in South Asia's rice-maize systems. Evidence from Bangladesh. Field Crops Research. 2014. P. 85-98.

6. Asfaw S., Maggio G. Gender integration into climate-smart agriculture. Tools for data collection and analysis for policy and research. Food and Agriculture Organization of the United Nations. Rome, 2016. $20 \mathrm{p}$.

7. McCarthy N. Understanding agricultural households' adaptation to climate change and implications for mitigation: land management and investment options. Integrated Surveys on Agriculture. Washington D.C., USA: LEAD Analytics Inc. 2011. P. 42-47.

8. Снеговой В. С., Гаврилица А. О. Орошение: от древнего искусства до современной науки. Кишинев: Штипнца, 1989. 135 с.

9. Нетіс I. T. Зміна клімату в зоні зрошення. Зрошуване землеробство. 1994. Вип. 39. С. 7-12.

10. Сніговий В. С., Жуйков Г. С., Димов О. М. Економічні важелі еколого-безпечного ведення землеробства на зрошуваних землях Південного Степу. Агроекологічний журнал. Київ, 2003. С. 32-37.

11. Fischer R. A., Byerlee D., Edmeades G. O. Crop yields and global food security: Will yield increase continue to feed the world? Australian Centre for International Agricultural Research. 2014. No. 158. P. 52-59.

12. Resource-smart technology. Bridging the design gap between the developed and developing worlds. URL: https://www.ideglobal.org/story/ resource-smart-technology\# (дата звернення 12.01.2019).

\section{Information about the author:} Vozhegova R. A., Doctor of Agricultural Sciences, Professor,

Corresponding Member of NAAS, Vice-head of the Plant Breeding Department, Institute of Irrigated Agriculture of the National Academy of Agrarian Sciences of Ukraine Kherson, Naddniprianske, 73483, Ukraine 